\title{
The Discourses of Romanticism and Heroism in the Post-Soviet Kyrgyzstan
}

\author{
Aijarkyn Kojobekova
}

\begin{abstract}
After the two so-called "colored revolutions" of March 24, 2005 and April 7, 2010 in Kyrgyzstan the ideas about the future development produced by political, traditional elite groups and academics are shaped into the certain discourses that reflect socio-cultural and political projects including real events and processes along with imagined reality. Among the inconsistent and incoherent discourses which take place in the social rhetoric of Kyrgyzstan, two dominant discourses - about Kyrgyz nomads and National heroes - have provoked ardent debates for many years. This article describes and analyzes the above mentioned discourses in order to reveal their contents, character and effects. I will present the results of my field research that includes the analysis of publications, political leaders' speeches, transcript materials from different intellectual group discussions, interviews with academics and participants of April 7 "revolution". I will illustrate that these discourses cover both political and socio-cultural issues connected with the imagined reality instead of solving short-term and long-term problems in certain aspects of Kyrgyzstan life. I believe that under the umbrella of political Romanticism they reflect an intention of some elite groups to have much more influence on the political processes and to redistribute symbolical power.
\end{abstract}

Index Terms-Discourse, heroization, legitimation, national heroes.

\section{INTRODUCTION}

Kyrgyzstan is a small Central Asian country with the population about six million people and a parliamentary political system. After the two so-called "colored revolutions" of 2005 and 2010 years it is torn by different ideas about the future development produced by different political, traditional elite groups and academics. These ideas are shaped into the certain discourses where discourses reflect socio-cultural and political projects including real events and processes along with desired reality. Among inconsistent and incoherent discourses which take place in the social rhetoric of Kyrgyzstan, two dominant discourses about Kyrgyz nomads and National heroes - have provoked ardent debates for many years. While the former has been heatedly discussed by historians, politicians and public figures since the dissolution of the Soviet Union, the latter has been played as a political mean for the last three years.

Manuscript received August 1, 2013; revised October 17, 2013. The author gratefully acknowledges the financial support of the Central Asia and Caucasus Research and Training Initiative (CARTI) funded by the Open Society Foundations and administered through its International Higher Education Support Program (grant ID: 30016136).

Aijarkyn Kojobekova is with the International University of Central Asia, Tokmok city, Kyrgyzstan (e-mail: akojobekova@gmail.com).
The discourse about Kyrgyz nomads has been prominent in the number of publications claiming that the nomadic life style of Kyrgyz people in the past and the nomadic spirit in the present are a guarantee of a successful democratic society and parliamentarianism. As regards the National heroes discourse, it appeared after dramatic events of April 7 in 2010 when about ninety demonstrators were killed and more than thousand were wounded in the protest meeting against ex-President Kurmanbek Bakiev's regime in the skirmish between military men standing guard over the Government house and protesters. The killed people were awarded posthumously by the title of National heroes. The political authority as represented by the President of Kyrgyzstan keeps claiming that these people's death is heroic because they sacrificed themselves for the sake of the future happiness of all citizens of Kyrgyzstan. However, many people who are not engaged in political activity have some doubts about such a political assertion for many reasons which will be considered later. In spite of many publications in the tide of these discourses, their character, reasons behind them and possible effects have not been fully studied.

Although these discourses are aimed at various effects on society, I argue that they may be covered by the umbrella of political Romanticism. Political Romanticism in this context is far from the European literature movement of seventeenth century. Primarily, it covers the social and political situation in which many discourses are suffering from the lack of concrete ideas how to implement desired social projects. This political Romanticism in Kyrgyzstan includes an idea of Heroism with the process of Heroization as an attempt to reconstruct history and the perception of a certain social situation through a number of historical heroes and the mythologization of the past in order to find something eternal, stable and monumental.

The theoretical grounds of Ernesto Laclau and Chantal Mouffe, Norman Fairclough's critical discourse analysis and his concept of intertextuality [1] as well as rhetorical political analysis allow me to demonstrate how the dominant discourse may be changed and the new social world or at least its perception can be reconstructed. According to E. Laclau and Ch. Mouffe any discourse is a specific force, which forms and shapes the social world by the dint of continuously changing values [2]. Norman Fairclough indicates it as "a practice not just of representing the world, but of signifying the world, constituting and constructing the world in meaning" [3]. The discourse is a linguistic reflection of the social world reconstruction; reflection of the reality in which people dwell and their desired reality at the same time, that is full of human intentions, emotional and psychological reactions and behavioral patterns. Moreover, within the frames of the politically given construct its variants are 
constituted either on the level of the particular social or ethnic groups, and individuals as well. In this sense, political authority tends to strengthen the dominant or hegemonic discourse about the social world as some kind of integrity, which inherent its own inner structure and stable elements. The suggested model of the social world is aimed at the approval of a certain social-cosmic order, the hierarchy of authority, its legitimation and sacralization as necessary. It is worth noting that different discourses, generated by political authority itself and different social, ethnical, cultural groups, arise in the period of social upheavals, transformation of the political system, reallocation of authoritative capital, both material and symbolic. Discourses produce various social attitudes and intentions, structure the social world in the certain configuration of its objects, features and functions, by means of which all essential ontological, epistemological and axiological bases for an individual and the society further will be established and normalized. Ethno-political discourses contain a complete collection of thoughts, beliefs, and skills, historical and spiritual experiences that reflect the natural and cultural, emotional and rational, individual and social components. Briefly, any discourse is a specific way how to understand, explain, and talk about a certain aspect of the world or the world itself. Therefore, all sorts of discursive projects have requirements to change the political or the social relationships.

This article describes and analyzes the above mentioned discourses in order to reveal their contents, character and effects. I believe that they reflect an intention of some elite groups to have much more influence on the political processes and to redistribute symbolical power. Since these discourses are not supported by material resources and practical means for application, they are rather pipe dreams, empty declarations and emotional appeals than feasible social projects for the development. At the same time these two discourses are aimed at finding something stable and unchangeable in the face of the increasing influence of the globalized world where countries suffered from the lack of resources and ill management have to find ways of survival. The analysis of publications, political leaders' speeches, transcript materials from different intellectual group discussions ${ }^{2}$ illustrates that these discourses about Kyrgyz nomads and National heroes cover both political and socio-cultural issues connected with the desired reality instead of solving short-term and long-term problems in certain aspects of Kyrgyzstan's life.

I will develop the idea about National heroes discourse in the context of the legitimization of power and the reconstruction of history, reveal the main ideas of the discourse about nomads, represent the reasons behind this discourse, and designate possible effects on socio-cultural and political situation as well. Particular attention will be paid to the discourses' struggle as a specific means of communication and understanding of the social world. The conclusion highlights the possible consequences of these discourses for Kyrgyzstan for the long-term perspectives.

\footnotetext{
${ }^{2}$ The original texts of speeches, transcripts, and publications used in the article are in Russian or Kyrgyz languages. Translations are provided by the author of the article.
}

\section{Discourses About NAtional Heroes AND KYRGYZ NOMADS}

On the $7^{\text {th }}$ of April 2010 eighty seven people were killed and more than thousand injured when the mass protest was being forcefully dispersed near the Government house at the Ala-Too square in Bishkek. People's dissatisfaction with the social policy of the authorities resulted in mass protests which later turned into unrest across the entire country. Protests and clashes led to President Kurmanbek Bakiyev being removed from presidency who later fled to Belarus. Once the head of the state was ousted all the killed were conferred officially the titles of National heroes and were buried on the famous memorial complex Ata-Beyit, where the outstanding cultural, scientific and public figures as victims of the Stalinist repressions had been interred. The reason for such awarding was their struggle against authoritarian regime headed by the ex-President Bakiev and their self-sacrifice in the name of people's freedom. Their families received financial compensation and new apartments. Every year a ceremony of commemoration (eskerüü) with official speeches of high-ranking politicians has been conducted as a part of heroization process. Strong polemics about this fact have been continued for three years and still have provoked different assertions regarding the April events. Nevertheless, academics have not expressed decisive conceptual opinion regarding the April events and the consequences [4]. I believe that such a kind of heroization that Kyrgyzstanis had on the $7^{\text {th }}$ of April 2010 is associated with the process of legitimation of the new political power which is represented by the same political figures which have hold key positions before and between two "colored revolutions" [5], [6]. General public has ambiguous attitude towards these deaths because it gave rise to mixed feelings and interpretations. There were many different emotions and ideas involved in the events that are far from political intention per se, meanwhile the main course of official interpretation had the character of political legitimation. I will show that there is some gulf between the official point of view and public evaluation regarding these events and especially so-called "heroisation" in the cultural sense of "baatyrdyk" or "kaarmandyk" (heroism). For Kyrgyz people the idea of "baatyr" (hero) along with its effect on people life has played significant role for a long period which is reflected in its epic heritage [7], [8]. One of the important parts is the process of becoming a "baatyr": his personal life and related activities. Thereby, interpretations of the $7^{\text {th }}$ April events can be equally bound with the political purposes and with the cultural attempt to justify untimely death of young folks, the youngest of whom were eighteen years old. The official and public opinions regarding the April events do not completely coincide in the context of heroism but rather reflect distinctive attitude towards the allegedly new political power. I will highlight in the succeeding passages differences in views of the political power in the person of the President, representatives of traditional elites, academic community and students as well.

In the official discourse the $7^{\text {th }}$ April is considered as a self-conscious sacrifice of participants for the sake of better future of Kyrgyzstan, political freedom and social welfare that is obviously sounded in the following speeches of the 
first political figures: ex-President Rosa Otunbaeva's (served as the President of Kyrgyzstan from 7 April 2010 until 1 December 2011 and launched the discourse about the fallen participants of April 7 as National heroes) speeches: the speech on the ceremony of delivering of keys from apartments in two high-rise buildings to families of victims of April 7 (6 April, 2011), the speech devoted to the unveiling of the memorial in honor of fallen participants of April 7 at Ata-Beyit memorial complex (16 November, 2011), the speech "Our dream is to become Switzerland!" (5 September 2012); the speech on UN General Assembly (23 September, 2011); interview to the newspaper "Alibi" ("And longer centuries a year lasted") (28 December, 2010), the interview to AKIpress "People of Kyrgyzstan. A private story" (AKIpress. 2010); the current President of Kyrgyzstan Almazbek Atambaev's speeches: the inaugural speech (1 December 2011), the unveiling of the memorial in honor of fallen participants of April 7 at Ata-Beyit complex (16 November, 2011), the speech devoted to the anniversary of March revolution of March 24 (23 March, 2012), the unveiling of the memorial in commemoration of fallen participants of April 7 (7 April 2012), the speech in commemoration of victims of Aksy events of 2005 (protests at the Aksy locality provoked the first so called "Tulip revolution" in Kyrgyzstan) (17 March, 2012) and his speech on the third anniversary of April events (7 April 2013). In Rosa Otunbaeva's speech of April 6, 2011 there are such words as "A year ago the people rebelled against the dictatorship of the former authorities. The heroism of those killed in the April events will never be forgotten. Their names will be written in golden letters in the history". In the speech of November 16, 2011 Rosa Otunbaeva said: “... unfortunately, bloodthirsty power again shed the blood of innocent people, again repeated the dark pages of history, with a blurred, unbearable grief, tears and violent actions, from which the heart grows cold. In April 2010 our young men gave their lives for freedom, for the future of Kyrgyzstan. Today we remember each character the April Revolution, faithfully keeping his name in our hearts. The names of our young lads (djigit), flying, like cranes, the wedge for wedge, with sadness echo in every heart ..." [9], and then "Last year in April, the Kyrgyz young lads (djigit) proved that spirit of Manas is alive in djigits, that we are the descendants of a great nation with honor defending their dignity. They have glorified the Kyrgyz people all over the world. In the words of Russian Prime Minister Vladimir Putin, at the beginning of the big changes, the social movements that have taken place in the Middle East, which is called the Arab spring, and then in other parts of the world, is Kyrgyzstan, it is a certainty. We will not be wrong if we say that our revolution marked the beginning of a new era." [10] The current President Almazbek Atambaev in his speech of April 7, 2012 said: "Today is the second anniversary of the April revolution. We gathered at the Ala-Too Square, in the very place where the April 7, 2010 held the line of the struggle between good and evil, between the forces of light and the forces of darkness, between fighting for their freedom the people of Kyrgyzstan and criminal regime, which had a stranglehold on the power". [11]

All these speeches which are full of pride and dignity about the second revolution and its heroes have depicted the dramatic events of 2010 by means of metaphors, pretentious analogies and comparisons that make one recall a political truism which claims that the poorer and the weaker the state the more metaphorical and pompous the speeches of its official leaders. The discourse of National heroes is not limited by the April events but is grounded on the other widely proliferated discourse about Kyrgyz nomadism. The discourse about Kyrgyz people as the heirs of nomadic civilization which incorporate free spirit of the nomads is one of the most enduring discourses that have been played by both political and traditional cultural elite for more than twenty years.[12] For an example, "nomads were never in a part of any empire - they were always (in virtue of their constantly changed residence) keeping own self-sufficiency, customs and culture what we can't say about settled people who were strongly affected by conquerors language, faith and culture". [13] In this context in official speeches the idea of free, independent and democratically oriented genuine Kyrgyz culture has determined public protest against Bakiev's authoritarian regime in 2010. This proud and just Kyrgyz nomadic spirit survived in defiance of the Tsarist Russian Empire, the totalitarian Soviet system and awakened ordinary Kyrgyz people to start the struggle with authority that had violated the principles of social justice and freedom.

The peculiar ideas of vindicating the $7^{\text {th }}$ April's bloodshed clearly demonstrate that political authority as represented by the President has tried to convince people of the historical meaning of that day as well as to dodge responsibility for that putting the blame on the Bakiev's regime at all. In November 16, 2011 the President of Kyrgyzstan Almazbek Atambaev in his speech dedicated to the opening the memorial to the men who died in events of April the $7^{\text {th }}, 2010$ in Bishkek city said: "Our heroes by their death showed us the road to the democracy. We will never have the despotism. April the $7^{\text {th }}$ became a beginning of the end of all tyrannical policies on the planet (here one can take a hint to "Arab spring"). People had seen that authority's strength is in the trust of people and not in the sniper rifles. If people do not believe in this authority the threat of tanks or automatic weapons and cannons will not save it" - noticed the president [14]. "What would happen to the country if there were no heroes? After all they could have sit on the fence or run to the warm countries, but they went out to the square and died in order that people could live happily. Herein is the core. Nobody made them do it; nobody knocked at their doors and invited them. They went out on their own and died for the future of our children and grandchildren" [14]. "April the $7^{\text {th }}$ means to me the same as what May the $9^{\text {th }}$ means to veterans of the Great Patriotic War", [15] In a letter with a request for financial support towards the construction works of the monument, sacred to the memory of the people who died during the tragic occurrences which took place on the central square Ala-Too of Bishkek city on April the $7^{\text {th }}, 2010$ A. Atambaev writes: "As you remember, on that tragic day thousands of our compatriots went out on the square to express their dissidence with K. Bakiev's policy of tribal-familial government, which intended to enrich a small group of people close to him. As a result of unlawful actions of the authorities aimed to disperse the demonstrators, dozens 
of people were killed and more than a thousand people were injured and maimed. But despite the desperate resistance of the anti-popular regime of Bakiev, ordinary people overthrew him from the power and established the truly public government in the Republic, based on the principles of democracy, freedom of speech and the rule of law" [16]. The current President repeatedly emphasized: "Our people has never bowed the knee to any authority. The ancient and proud people have had long history of fighting for freedom. Kyrgyz people have always been willing to give their lives for freedom and justice. April the $7^{\text {th }}$ has convinced the whole world herein" [17]. One can see that this rhetoric claims the rational choice of participants of April the $7^{\text {th }}$ to confront the authoritarian regime till death although in fact many of them were at the square on that day by chance as curious onlookers [18], [19].

These fragments of the main statements of the first political figures demonstrate the presence of intertextuality in the spirit of Fairclough related to combination of various components of different discourses within frames of the one that creates an effect of ambiguous or given by the author perception. Fragments sustained in the frames of opposition "power - society". They are combined with high rhetoric sentences ("with their deaths showed us the road to the democracy", "on that tragic day"), political clichés ("policy of tribal-familial government", "as a result of unlawful actions of the authorities", "public government, based on the principles of democracy, freedom of speech and the rule of law") and conversational style ("sit on the fence" "run to the warm countries"), what makes from one side this event immersive with live of every person within this country ("they went out on their own and died for the future of our children and grandchildren") and at the same time raises significance of the happened event, bringing it far beyond the certain area ("April the $7^{\text {th }}$ became a beginning of the end of all tyrannical policies on the planet"). This year on the $7^{\text {th }}$ of April the president Atambaev made an appeal regarding the third anniversary of April events which was also in the same course: “On April 7, 2010 people's patience was exhausted. On that rainy spring day tens of thousands of ordinary Kyrgyz people as a sign of protest against the arbitrary exercise of power and lawlessness took to the streets and squares of the country. They fought for their country, for the future of their children. They fought for the rule of law and justice. It was a struggle between good and evil, between light and darkness. Under fire at the square people were being killed. But in place of the fallen the others got up. It was a day when the teachers and students, doctors, workers, farmers ordinary workers were fighting for their future, for a just and free country. The past three years, too short time so we could heal the wounds in the hearts of the people. But the way which the country has gone for these three years is commensurable with decades. We have changed over the years. We have become stronger." Such a discourse does not just build up a certain attitude to the event and its participants, but in essence service to the process of legitimation of the new government by the heroization of the dead (whose actions are equated with the exploits of the Great Patriotic War veterans) who sacrificed their lives for "the establishment the truly public government in the Republic".
Simultaneously political authority has excluded from the official discourse some disputable questions such as "Why oppositional leaders who brought protesters to the square were not among them during exchange of fire? Why the elite military Special Forces have been declared criminals for carrying out their duty in protecting the Government House? It should be pointed out that the judicial process has still been going on without any obvious result. [20] Why among people who received the title of National heroes are those who had not died from gunshot wounds? [19] As many other sore questions raised by academics, students and many public figures are able to object this course of official rhetoric. For instance, although many experts and scholars who investigate the "colored revolutions" have paid much attention to their well-organized character with mobilizing thousand different people, choice of place and time for the first protest actions, appropriate eloquent slogans and undoubtedly key players and money behind them, in Kyrgyz political discourse these issues are passed over in silence. In this sense the given political discourse not only asserts some ideas regarding April events but also excludes or obfuscates potentially dangerous issues for it.

It should be pointed out that this kind of ideological legitimation of power and justification of the bloody April 7 was supplemented by burial with honors at the memorial complex Ata-Beyit, opening the permanent exhibition entitled "The Motherland will not forget their names" devoted to the National heroes at the National historic museum which is used to be Lenin's museum in the Soviet time (one could not help taking a notice that there is no conceptual idea of the memorial exhibition to reveal any symbolic meanings. This bizarrely eclectic collection of different things (books, notes, pictures, clothes, and etc.) of the fallen participants of April 7 has been placed among the displays, pictures and sculptures related to Lenin's life and activity which cause some weird visual effect. The museum workers interviewed by me claim that it is hard to grasp the meaning of April events and impossible to identify personal contribution of participants. So this exhibition is merely to remember that day. Interviewed by me 25 academics working in the field of Kyrgyz culture have not attended this exhibition, most of them have never heard about it. Therefore opening the exhibition, erecting a huge marble monument at the Ala-Too square symbolizing clearly the struggle between good and evil but without reflecting the specificity of that situation, and hanging memorial plaques with names of National heroes on the fence of the Government House are components of this ideological legitimation of power and justification of the dramatic April events. I believe that ongoing public disputes about burial at Ata-Beyit complex, the character of the exhibition, different relation to the monument as well as lack of knowledge of ordinary people about National heroes reflects the fact that official power just claimed the idea of public heroism of April the $7^{\text {th }}$, but the process of heroization in the broad ideological sense has not been completed yet and has not fully coincided with the idea of heroism in Kyrgyz culture either. In addition, awarding five hundred participants of those events among them mostly members of leading political parties of Kyrgyzstan with the title of the Hero of April 7 (The Hero of April 7) has 
depreciated the meaning of heroism and a hero as itself with a deep spiritual context behind it in the eyes of the public that complains on annoying behavior of hundreds of newly-made heroes who are demanding more and more privileges [21].

As regards public opinion about the second revolution in Kyrgyzstan there is no unity on it. It is noteworthy that the discourse-analysis of koshoktor, yrlar (songs-lamentations) devoted to the fallen participants of April 7 written by Kyrgyz akyns (improvising poets and singers) Djenishbek Djumakadyr, Elmirbek Imanaliev, Aaly Tutkuchev, Azamat Bolgonbaev, Amantai Kutmanaliev, Shekerek Adylov, Anatai Omurkanov, Asankul Buudaichiev, Turgunbek Bekbolotov, Muktar Shermatov, Kalbubu Sarieva, Guldjamila Shakirova, Djediger Saalaev, Ozubek Abdykalykov, Aibek Tumonbaev, Sagynbai Almakunov authors tell about Bakiev's regime, national grievances, Kyrgyz dignity, and spirit of epic heroes - Manas, Bakai, and people faced death for the sake of future. [22] The major portion of the content is devoted to the power which doomed the people to the abject poverty, tortures, pain, and grief. The leading idea is confrontation of the power and people, public heart overflowed with the sense of justice and willingness to struggle for the better life. This idea coincides with official rhetoric sounded by political leaders. The fallen in these songs-lamentations are converted into baatyrs (heroes) sacrificed themselves in the violent struggle for justice. The curious point is that the names of Bakiev, his brother Djanysh, his son Maksim are becoming symbolic names of unscrupulous rulers and authoritarian regime as itself. The statement about necessity to remember the names of the fallen is becoming metaphorical in sense of keeping in mind this bloody event at all. They are considered as a collective image, as an integral force without bright and vivid individuality inherent in traditional Kyrgyz heroes with their unique and expressive features. The most interesting point in these songs-lamentations is in fact that the broad concepts of a hero and heroism in Kyrgyz culture, including the sampled life, positive activity in the certain context, protecting people from enemies along with carrying out raids on them, right decisions regarding complicated problems, performance of his official duty, serving interests of the people and "the hero's virtues are measured by his generosity and deep concern for the poor, namely: orphans, widows, the old and beggars" [23], all these have been reduced to the act of death only. I argue that this type of heroism of April the $7^{\text {th }}$ promoted by the authority is not able to provide people with the role-models for the further development of the country and is far beyond the constructive image of a socially active type of personality. Moreover, this discourse is easily converting the concept of kaarman (a hero) into the concept of kurman (a victim) with its harmful consequences. At the same time it is difficult to avoid the fact that some representatives of traditional elite groups like manaschy (people who tell epic poem "Manas") share the idea expressed by the President about the effect of April the $7^{\text {th }}$ on the number of revolutions in the East, so called "Arab spring" as an ability of Kyrgyz spirit connected with nomadic life to influence not only within country but also well over its boundaries. People who are believed to have extrasensory perception have claimed that Kyrgyz people have a special mission to provide the world with genuine spirituality where April the $7^{\text {th }}$ is considered as one of the stages of spiritual arising which would lead to the radical regeneration both Kyrgyz people and the rest of the world. This is a new direction in the public discourse about nomadic spirit of Kyrgyz people which has taken a messianic shape.

Interviewing of academics, experts and scholars who investigate Kyrgyz culture about the meaning of heroic death and their evaluation of April tragedy I have found different points of view: first, it was not heroic death on April the $7^{\text {th }}$, but only a tragic bloody suppression of the public protest action; second, not all the fallen were self-consciously motivated, some of them were killed occasionally; third, it was the wrong decision to award all the fallen by the title of National heroes, however, it is very difficult to differentiate amidst them according to their activity; forth, the fallen people were really heroes who protested against authoritarian regime. No need of identifying who was self-motivated or killed by accident among them. The most important thing is to realize that we have some sort of a fault-line between two stages of the nation-building process: before April the 7th and after that day; fifth, on the one hand it is the process of political legitimation of the new power in order to vindicate political leaders who came to power after the 7 of April and who might have paid to participants for their active protest. On the other hand Kyrgyzstan needs these heroes to indicate the new stage of its development, to have something as a reference point for the further steps; sixth, nobody believes in official statements and claims, but we can suppose that in case of utter defeat of the April 7 protest in 2010, the official power would have condemned the fallen participants' actions and called them infringers of the law or even criminals. In difference from it in the public opinion anyway they would have been heroes and their heroization would have been much stronger than now. Such opinions partially contrast with the official discourse but do not reject the heroic component on that day when people did not leave the square in spite of firing, increasing number of wounded demonstrators, shouts and blood. Academics express their disagreement with the President Atambaev's comparison of the April participants with the participants of the Great Patriotic war or with the three hundred Spartans (the Hollywood version of the last battle of three hundred Spartans was being transmitted at that moment in Kyrgyzstan) by several reasons: the Great Patriotic war was against an external threat and it took four years with strict and clear requirements to giving the title of the Soviet Union Hero (for example, in the Second World War only 73 people from Kyrgyzstan were awarded by the title of the Soviet Union Hero), therefore it neither could be relevant comparison or positive for the nation building process; as regards Spartans, any comparisons with cinematographic personages especially grounded with greatly different culture do not assist in comprehension and evaluation of real socio-political events and processes. The latter comparison is just an attempt of authority to find support of the young part of population that is believed to be infatuated with such movies. At the current moment academics rather have discussed the socio-political and economic consequences of the so called second revolution with subjecting to doubts the 
"revolutionary" changes, where one can see the same political figures, high level of corruption and declining life of ordinary people than the ideological meaning of the title of National heroes, official appeals about April 7 or the effects of this heroisation as itself. According to the academics the official discourse is equally necessary for political leaders to justify their positions and families of fallen participants to be provided with consolation.

In addition, questionnaire of two hundred fifty students of Kyrgyz Russian Slovenic University in Bishkek and the International University of Central Asia in Tokmok city has displayed some distinctive perception of a hero concept and the April participants. A total of 250 respondents (152 women, $98 \mathrm{men}$ ) were enrolled in introductory Political science course. Respondents completed a questionnaire which consisted of 12 questions. They were asked to define the term hero and provided approximately one half of a page to write a response to each question about April 7 events.

TABLE I: PEOPLE WhO ARE RECOGNIZED By StUdENTS AS HEROES. (R -

\begin{tabular}{|l|l|c|l|l|}
\hline $\begin{array}{l}\text { Heroes } \\
\text { of the } \\
\text { Great } \\
\text { Patriotic } \\
\text { war }\end{array}$ & $\begin{array}{l}\text { Kyrgyz } \\
\text { heroes } \\
\text { (Manas, }\end{array}$ & $\begin{array}{l}\text { Chyngyz } \\
\text { Kurmandjan } \\
\text { Datka) }\end{array}$ & $\begin{array}{l}\text { National } \\
\text { guardsmen } \\
\text { Tilek } \\
\text { Adyshev and } \\
\text { Sagynbek } \\
\text { uulu } \\
\text { Tynchtykbek }\end{array}$ & $\begin{array}{l}\text { Collective } \\
\text { image of } \\
\text { heroes }\end{array}$ \\
\hline $171 \mathrm{R}$ & $52 \mathrm{R}$ & $7 \mathrm{R}$ & $20 \mathrm{R}$ & $250 \mathrm{R}$ \\
\hline
\end{tabular}

The image of a hero (Table I) for the most part of respondents (about 70\%) is associated with the Soviet time, especially with the heroes of the Great Patriotic war such as Cholponbay Tyuleberdiev who on August 6, 1942 closed with his body recess enemy bunker, ensuring the capture of the strategic base for offensive operations of the $6^{\text {th }}$ Army of the Voronezh Front, Panfilov heroes that stopped the forty tanks in passing Dubosekovo place and all were killed, and many others. It should be noted that students not only know their names but also describe in details their exploits with sense of pride and fascination.

On the second place (20\%) such Kyrgyz heroes as the great epic hero Manas and a historical figure Kurmanjan Datka goes by name of "The Queen of the South" and she is also known for her initial resistance to the annexation of that region by Russia. $8 \%$ considers as heroes two guardsmen of the National Guard Tilek Adyshev and Sagynbek uulu Tynchtykbek who on April 7, 2010 stood guard at the flagpole with the main symbol of the state, not dodging bullets and stones to the last. The famous Kyrgyz writer Chyngyz Atmatov glorified Kyrgyzstan with his talent is a hero for $2 \%$ of respondents. Moreover, all respondents indicated a collective image of heroes as people rescuing those who need their help (fire brigades, workers of the Ministry of Disaster Management, officers of law-enforcement agencies, etc.) as well as called personalities famous for their professional activity, individual achievements in different spheres (art, sport, business) whose actions should be emulated today. In this tendency the book of Iskender Begaliev "Heroes among us" published in 2012 the main idea of which according to the author is "consolidating ideology, patriotic education of the younger generation. It reflects the real stories of ordinary people who are worthy of respect and recognition to them as an example to educate young people. The book describes the history of sports, military, artists, doctors, champions. They all share the compassionate attitude towards others, love of country, courage, fortitude and generosity... ordinary people, whose heroism is not quite known to a wide range of people ...True heroes who live near us" [24]. While the political power is intending to develop the discourse about National heroes in the historical and global perspectives, young people are trying to find their ideals for the present moment of life with its daily troubles and achievements.

However, students' judgments about participants of the April events are unambiguous but more radical in comparison with academic community opinions. Almost equal split vote $(27 \%)$ of the respondents to assess the fallen participants in the events of April the $7^{\text {th }}$ as "Heroes", "Not Heroes", "Not all heroes" and $18 \%$ consider them as victims of circumstances or political manipulations (Table II).

TABLE II: STUDENTS' ATTITUDE TOWARDS FALLEN PARTICIPANTS OF

\begin{tabular}{|l|c|c|c|}
\hline \multicolumn{4}{|c|}{ APRIL 7, 2010. (R - RESPONDENTS) } \\
\hline Heroes & Not Heroes & $\begin{array}{l}\text { Not all } \\
\text { heroes }\end{array}$ & Victims \\
\hline 69R & $68 \mathrm{R}$ & $68 \mathrm{R}$ & $45 \mathrm{R}$ \\
\hline
\end{tabular}

Negative relation of students to the National heroes is determined by rumors that some participants were paid, others were just onlookers without any political beliefs, and the third ones according to medical reports were drunk or drugged. In addition, the most important point emphasized by students that demonstrators did not expect that they would be killed so no reason to speak about heroism. Nevertheless, no need to reject the fact that only a few of them were inspired by the necessity to change radically the unbearably hard political and social-economic situation and there is nothing left to do but regret that they were buried along with casuals. Because of these reasons for $54 \%$ of students they hardly deserve the title of National heroes (NH) (Table III).

TABLE III: ATtitUdE TOWARDS THE TITLE OF NATIONAL HEROES (NH) CONFERRED UPON FALLEN PARTICIPANTS OF APRIL 7, 2010. (R RESPONDENTS)

\begin{tabular}{|l|c|c|}
\hline $\begin{array}{l}\text { Deserve fully the } \\
\text { title of } \mathrm{NH}\end{array}$ & $\begin{array}{l}\text { Deserve scarcely } \\
\text { the title of } \mathrm{NH}\end{array}$ & $\begin{array}{l}\text { Not all deserve } \\
\text { the title of } \mathrm{NH}\end{array}$ \\
\hline $87 \mathrm{R}$ & $135 \mathrm{R}$ & $28 \mathrm{R}$ \\
\hline
\end{tabular}

For example, one student wrote: "I know that in the village "Komsomol" one of the old streets was renamed in honor of the "imaginary hero", although all the inhabitants of that village know that it was a man pathologically ill with alcoholism and under drug addiction. How can such a man be considered a hero of the Kyrgyz Republic?" For nearly half respondents, the necessity to provide people with consolation after the bloodshed and justify the actions of oppositional leaders responsible for that is the only reason behind the official heroization of the April events. One of the irritating facts for students is burial on the Ata-Beyit a man who later was identified as alive. [25] In spite of that $35 \%$ of students are sure that this is well-deserved reward due to their bravery and willingness to confront the authoritarian machine while many of ordinary people and politicians were only thinking about their own private interest. 
One of the respondents wrote: "After those events (April 7) for some reason people have said a lot about the spirit of Manas. I heard the story of a man who retold what a young woman bringing her children to a kindergarten saw in the sky. In her descriptions in the sky over the Ala-Too square Manas appeared with his forty warriors, they outlined three circles around the square and disappeared. Much has been said that the protesters were supported and blessed by the spirit of Manas". Then he continued: "Personally, I am very serious about this subject, and I revere Manas. And to me it does not matter the opinions of those "clever" people who condemn and criticize this topic. Personally to me it speaks only of their insufficient spiritual development". The idea about Manas who gave his blessing to the participants of April protest is shared by $10 \%$ of respondents who claim that heroism of Kyrgyz people is determined by spiritual ties with ancestors who lived in the conditions of real nomadic democracy with true public governing and fair social-cosmic order.

After "revolutionary" transformations of April 2010, official political authority announces ideas about conceptually new character of the government. Elected in December 2011 President of the Kyrgyzstan A. Atambaev said: "Last election showed that the public chooses for continuation of the reforms. The public perhaps voted not for Atambaev, but so that it could be quiet in the country henceforth, stability appeared and so that the public could decide own destiny. The public does not want autocracy and despotism to be from now on. Kyrgyzstan should have public authority". [26] In contrast to the official discourse students do not share its optimism and emotionality about constructive transformation of the political systems which seem to remain being corrupted and driven by personal political ambitions. Disappointment and dissatisfaction with the post-revolutionary processes in the state distinguish students' attitude towards the April heroes and the heroization that perceived as legitimation of power and desperate attempts of politicians to quell off emotions of fallen demonstrators' families and relatives.

Discursive clashes of official authority and cultural, traditional elites contribute to the change and the construction of social reality, which continues to retain designated in the opposition of "the authority - the society", where both the government and the society mythologize and romanticize the processes ongoing in the country. Particularly, the discourse about nomads practically drives out any ideas concerning a fact that Kyrgyz people already for century have not been nomads, and indeed they never were nomads strictly in sense of the word. This discourse practically ignores the influence of the Soviet period on socio-cultural and political processes. At the same time the idea of nomadism is associated with the "awakening" of ethnic identity, "the call of blood", which should make the Kyrgyz people to through off their shoulders all that is foreign, on the morrow of which a total life upgrade should began for all the Kyrgyz folk and those who share with him his fate. [27]

\section{CONCLUSION}

Since the public evaluation of National heroes is wavering one can say that heroization of the April events is first of all a political act of ideological legitimation which was spontaneously provoked by the April bloodshed and potential threat of disturbances when according to majority of opinions of academics and students political power had to take measures immediately to avoid the next wave of public anger which explains these hasty decisions and actions.

The heroization of the fallen participants of April the $7^{\text {th }}$ seems to be partially connected with the necessity to create a new state history with its present day heroes. What is interesting at this point is that nobody knows the names of these participants. So I can assume here that there is no need to remember eighty seven names, but just to bear firmly in mind this collective heroism which is more effective and powerful than individual acts of sacrifice. This point is new for Kyrgyz history where one can find many famous heroes whose names are well-known. At the same time these National heroes unlikely to be role-models whose actions and moral virtues could be emulated.

Presented discourses are expressed in the spirit of "romanticism in politics" which "comes from belief in the possibility of a consistent and thorough alteration of reality, according to accepted principles of the project" [28]. One consequence of this romanticism is declared at a political level, the idea of a "democratic people, making their choices and building their future" that in the quasi-democracy becomes a bitter irony. In this case the choice of the people always interfere, "intrigues of enemies" both inner and external (we have to note that in many countries during the revolutions the model of "enlightened vanguard" and the passive society was used). For the romanticism common are the confidence in the knowledge of "human nature" and the lack of understanding that between idea, theory, philosophy and reality is a series of various related circumstances and factors that could seriously change the process and outcomes of even the most clear and accepted by all idea. Romantic thinking is always black and white, it has its own determination and consistency until the first serious setbacks or obstacles, followed afterwards by "despondency, splits, non-action, divergence of different camps" [28].

The discourses submitted for consideration do not cover all the discursive variety in the public rhetoric of Kyrgyzstan, but they are among dominating ones. I would like to point out a number of general characteristics: firstly, highlighting of some elements, facts, events and at the same time, excluding of others from public discussing, which however points at the attempt to set dominant discourse. Secondly, each discourse appeals to ideal images and constructs, behind which is the complex social reality, which does not obey the strict schematization. Thirdly, stated discourses use the means of romantization of the highlighted key events in historical development. Fourthly, each of them weakly tied with practical mechanisms of implementation of declared ideals in everyday practice. Fifthly, these two discourses are very close to each other because the first one reflects the heroic past of Kyrgyz people who allegedly have principles of democracy in their blood; the second one claims the present reflection of this democratic unconsciousness in the protest activity of participants of April 7. Here, the idea about justice as a main principle for the nomadic social world has been 
represented in these discourses. Sixthly, the concepts of heroism and a hero as key concepts in Kyrgyz culture have been reduced in their meaning that lead to their conceptual devaluation. Seventhly, the discourse about Kyrgyz nomads has represented in a new messianic shape which can be comprehended in the context of the terror of history when many peoples and cultures have disappeared being incapable to react appropriately to the challenges of the changing world with the new geopolitical order and economic conditions. Eighthly, the bigger part of all presented discursive compositions are designing and constructing new social reality, by reference to retrospection - related to the past, which obtains quite schematic, conditional, and romanticized features.

\section{ACKNOWLEDGMENT}

Author thanks Prof. Dr. Roland Hardenberg for his guidance throughout the preparation, research, and writing of this article.

\section{REFERENCES}

[1] Fairclough, Analysing Discourse: Textual Analysis for Social Research, London: Routledge, 2003, pp. 45.

[2] E. Laclau and C. Mouffe, Hegemony and Socialist Strategy: towards a Radical Democratic Politics, London: Verso, 1985, pp. 16.

[3] N. Fairclough, Discourse and Social Change, Polity Press in association with Blackwell Publishing Ltd., 1992, pp. 64.

[4] Verbatim Record of the Round Table April Events of 2010 in Kyrgyzstan in the Eyes of Participants, Researches and Experts, Bishkek, American University of Central Asia, April 9, 2013.

[5] A. Arzymatova. Kyrgyz revolutions and the present day political process in Kyrgyzstan. [Online]. Available: http://www.ia-centr.ru/expert/13076/

[6] O. Togusakov, April People's Revolution: The Lessons of History and Vision for the Future of Kyrgyzstan, Bishkek: Biyiktik, 2011, pp. 51

[7] B. Yunusaliev. The Kyrgyz Heroic Epic "Manas". [Online]. Available: http://www.eposmanas.ru/?page $=626$.

[8] N. Tadina, Hero's Morality In The Kyrgyz Epos "Manas" and Altaic Epos "Alyp-Manash"/ Epic "Manas" as a Historic-Ethnographic Source, Bishkek, 1995, pp. 45-47.

[9] The President Roza Otunbayeva took part in the opening of a monument in honor of the fallen heroes of April 7, 2010. [Online] Available: http://www.time.kg/tochnoe-vremya/2582-prezident-roz a-otunbaeva-prinyala-uchastie-v-otkrytii-monumentalnogo-pamyatnik a-v-chest-pogibshih-geroev-7-aprelya-2010-goda.html.

[10] Roza Otunbayeva. The people of Kyrgyzstan. Personal History. [Online]. Available: http://www.akipress.org/people/news:341/.

[11] A memorial to people killed in the Aksy and April events has opened in Bishkek. [Online]. Available: http://www.knews.kg/ru/society/14021/

[12] C. Seidahmatova, "Thinking of the nomadic democracy," 2011, pp. 3.

[13] M. Suyunbaev, "Identity and specifics of the nomads and mountains civilizations of Central Eurasia," in Proc. Conf. Universal and national in philosophy, Bishkek, Kyrgyz-Russian Slovenic Univ. 2005, pp. 191
[14] The monument to victims of April 7 has been erected in "Ata-Beyit". [Online]. Available: http://www.report.kg/people/13643/.

[15] A. Atambaev. (April 7, 2010). The beginning of the end of all oppressive regimes on the planet. [Online]. Available: http://www.knews.kg/ru/society/6148/.

[16] Letter to the Director General of "Shoro" Company. [Online]. Available: http://www. paruskg.i...011/07/18/46945.

[17] A. Atambayev. Speech at the official inauguration of the President of the Kyrgyz Republic. [Online]. Available: http://www.president.kg/ru/posts/4f14eae5f4d5 527351000002.

[18] April $7-$ it is a revolution or a coup d'etat. [Online]. Available: http://www.gezitter.org/politic/10272_7_aprelya_revolyutsiya_ili_pe revorot/.

[19] "April 7" in Kyrgyzstan: Is it the court or tribunal? Revenge or retribution? [Online]. Available: http://www.kyrgyzstan.russian-club.net/article_2569.html.

[20] C. Dzhakupova, The Kyrgyz authorities should not take the ostrich position. The Problems are to be Solved. [Online] Available: http://rus.kg/news/vlast/9327-cholpon-dzhakupova-vlasti-yrgyzstan ane-dolzhny-prinimat-poziciyu-strausa-problemy-nuzhno-reshat.Ht $\mathrm{ml}$.

[21] Participants of the April coup are asking to be equated to the veterans of the Great Patriotic war. [Online]. Available: http://www.sayasat.kg/index.php?option=com_articletags\&view=tag \&id=94\&Itemid=101\&lang $=$ ru

[22] Heroes of April 7, Bishkek: Biyiktik, 2010, pp. 28-49.

[23] E. M. Kuchumkulova, "Kyrgyz nomadic customs and the impact of re-Islamization after independence," $\mathrm{Ph}$. D. dissertation, Univ. of Washington, Graduate School, 2007.

[24] Culture and Sport. [Online]. Available: http://www.knews.kg/culture/16366_iskender_begaliev_geroi_sredi_ nas_eto_kniga_o_dostoyneyshih_geroyah_kyirgyizstana/.

[25] Who buried? [Online]. Available: http://www.stan.tv/news/20509.

[26] News agency "24.kg". [Online]. Available: http://www.pr.kg /news $/ \mathrm{kg} / 2011 / 11 / 16 / 21256 /$.

[27] Verbatim Record of the Round Table Kyrgyz People in Pursuit of Everlasting, Mechanism of the spiritual self-preservation and public development, 2011, pp. 1-2.

[28] V. Demidov, Theory of Politics: Philosophical Approach, Moscow, 2001, pp. 277.

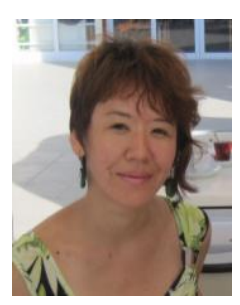

Aijarkyn Kojobekova was born in Kyrgyzstan in the $8^{\text {th }}$ of March, 1977. In 2007, she received her $\mathrm{PhD}$ in Philosophy at the Institute of Philosophy and Law, National Academy of sciences. Then in 2010 she was awarded the academic title of Docent (Associate professor) the National attestation commission of the Kyrgyz Republic. At the present moment she works at the International University of Central Asia (Kyrgyzstan) at the Department of International Relations. Her research interests are connected with the Kyrgyz culture and nation building process.

Dr. Kojobekova has an affiliation with Central Asia and the Caucasus Research and training Initiative (Open Society Institute Academic Fellowship Programme), Department of Social and Cultural Anthropology of the University of Tuebingen (Germany), Cultural Research Center "Aigine" (Kyrgyzstan), and Russian Philosophical Society. 